\title{
Karen Culture of Evangelism and Early Baptist Mission in Nineteenth Century Burma
}

\author{
Yoko Hayami* \\ Center for Southeast Asian Studies, Kyoto University, Japan \\ yhayami@cseas.kyoto-u.ac.jp
}

\begin{abstract}
The success story of nineteenth-century Baptist missionary work among minority ethnic groups in Burma was one well-known facet of the early beginnings of modern Protestant missions. Behind this success was the extensive travel and evangelizing work done by native Karen Christians. In the face of the unexpected speed and zeal with which the Karen converts spread the gospel, to which I apply the term "culture of evangelism", the Baptist mission in Burma was formed through an interactive process of continual self-reformulation, negotiation, and compromise on crucial matters such as baptism, ordination, self-support, division of roles, and language use. This has had far-reaching effects in shaping the Baptist churches in Myanmar today.
\end{abstract}

\section{Résumé}

L'histoire des succès de la mission baptiste parmi les minorités ethniques de Birmanie au XIXe siècle est un des aspects bien connus des tout premiers pas des missions protestantes modernes. Derrière ce succès, il y a les nombreux voyages et le travail d'évangélisation réalisés par les autochtones chrétiens karen. Face à la rapidité et au

* I am grateful to the American Baptist Historical Society archives for all the assistance in locating material, and to Saya Gwaw Tuu and Christine Tuu for their translation of passages from Hsah Too Ghaw. A very early version of this paper was first presented in the Kyoto-Cornell Joint International Workshop on Trans-national Southeast Asia: Paradigms, Histories, Vectors 2013, Kyoto. Subsequently, different versions of it have been presented in different contexts in academic meetings and small workshops. I thank all those who gave me comments and questions from those occasions, especially, Justin McDaniel, Masao Imamura, Prasit Leepreecha, Winai Bunlue and Jonathan Seitz on earlier versions of this paper.

(C) YOKO HAYAMI, 2018 | DOI:10.1163/18748945-03103006

This is an open access article distributed under the terms of the prevailing CC-BY license at the time of publication. 
zèle inattendus avec lesquels les convertis karen ont diffusé l'évangile - ce que je décris comme une «culture de l'évangélisation » -, la mission baptiste en Birmanie s' est constituée à travers un processus d' interactions continues d' auto-reformulation, de négociations et de compromis sur des questions aussi cruciales que le baptême, l'ordination, l'autofinancement (self-support), la division des rôles et l'usage des langues. Ce processus a eu des effets considérables sur la formation des églises baptistes actuelles en Birmanie.

\section{Keywords}

Burma - Baptist - evangelism - conversion - native agency - Karen

\section{Mots-clés}

Birmanie - baptisme - évangélisation - conversion - agencéité autochtone - Karen

\section{Introduction}

Despite the fact that Christians constitute less than twenty per cent of the Karen population on both sides of the Thai-Burma border, ${ }^{1}$ the wave of Karen conversion in early nineteenth-century Burma is a success story in the history of Protestant missions. ${ }^{2}$ Narratives regarding this wave of conversion have emphasized the role of foreign missionaries, whether to praise them for civilizing the wild forest-dwellers, or to condemn them for sowing the seeds of ethnic division, by forming ethnic churches that constitute the present-day Baptist church, the largest Protestant denomination in Myanmar today.

1 In this paper, 'Karen' refers mainly to Sgaw Karen speakers (who called themselves pga k'nyau) unless otherwise noted. In Thailand in 2008, the Karen population were said to number approximately 400,00o, the largest among the hill-dwelling minorities. In Burma in the 1980s, the Karen were said to constitute 7 percent ( 3.5 million) of the population. In order to differentiate the foreign missionaries who worked among the Karen on the one hand, and the native Karen who themselves worked as missionaries, in this article I will designate the latter as 'Karen evangelists'.

2 Since the discussion in this article is primarily on nineteenth and twentieth century Burma, unless referring to the present, this paper uses 'Burma'. 
It should be noted that the first Karen conversion took place within a few decades of 1792, the year that is often cited as marking the beginning of modern missions: when the English Baptist William Carey published an urgent call to world missions, An Enquiry into the Obligations of Christians to Use Means for the Conversion of the Heathens, and founded the Baptist Missionary Society in London, which set the tone for the modern worldwide missionary movement. Every new instance of missionary work, including those in Burma, was a fresh trial and endeavour of missionary practice. The arrival of the American missionary Adoniram Judson (1788-1850) in Burma was unmistakably a part of this mission movement, which had crossed over to the United States, where, amidst the wave of the 'Second Awakening', the American Board of Commissioners for Foreign Missions was founded in 1810.

The fruits of missionary work in Asia were the focus of great interest among the movement's supporters in both the United States and Europe. In response to this, missionaries in the field were under pressure to report their accomplishments, in order to secure the necessary funds, which were based on voluntary contributions. ${ }^{3}$ They needed to appeal to their audiences at home, conveying the difficulty of the task, and how lonely yet fruitful their endeavour was. What was drowned out amidst these reports was the work of the local converts. Missionaries had multiple responsibilities that kept them working primarily at the mission stations: the terrain they had to cover was vast, and their number was few. An obvious figure that has been obscured from this history is the native evangelist, who actually spent far more time with potential converts.

More recent work on mission history in Africa and South Asia has begun to pay attention to the role of the indigenous missionaries. ${ }^{4}$ Encounter between missionaries and the natives is now seen less as a unilateral process of domination and imposition of hegemonic truth, and more as an 'interaction', 5 mutual 'articulation, ${ }^{6}$ 'vernacularisation,, 7 and as a process of 'reciprocity', ${ }^{8}$ or even 'local appropriation' ${ }^{9}$ with 'unexpected consequences.' ${ }^{10}$ This goes hand in hand with an inevitable turn in the historical studies more generally of the

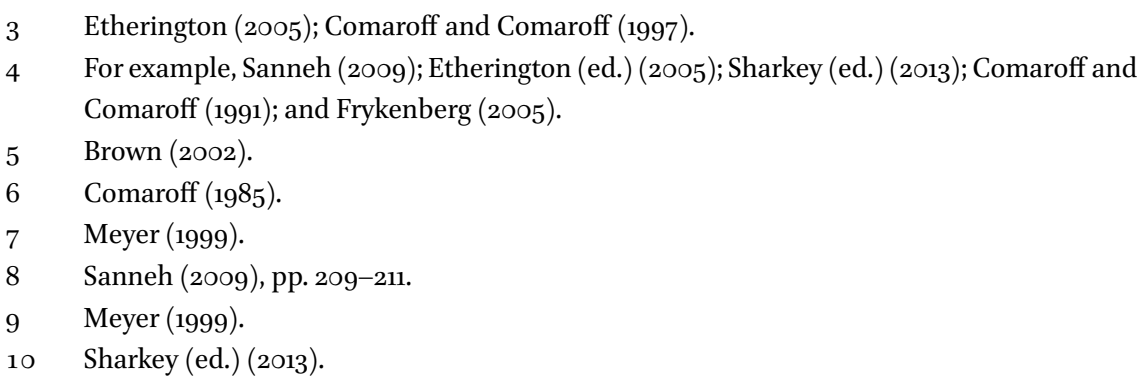


encounter with the West, and the ensuing processes. From the context of colonial America, those natives who knew their way around the woods were invaluable, as they were well-versed in forest survival, and could step in to downplay differences; play up areas of common ideology, interest, and experience across diverse customs and languages; and 'go into the particulars' in negotiation. ${ }^{11}$ These 'go-betweens', who lived between the two worlds going back and forth, are remarkably absent in official history. The 'alchemy of interpretation'12 and the very essence of the first encounter has been forgotten. Whether we call them the go-betweens, cultural brokers, intermediaries, or 'gateway groups',13 the native evangelists were agents who must be made visible in history in order to understand the process of modern missions and the acceptance of the gospel. In the case of the early Karen Baptist converts, I would go further to point out that not merely as mere go-betweens or intermediaries, they went out to proselytize on their own accord, driven by their own logic and zeal, developing a 'culture of evangelism,'14 through local appropriation of the missionary teachings.

Focusing only on the missionary side of the story would mean reproducing the monopoly on knowledge and interpretation, "a huge distortion because of course that monopoly did not exist".15 What takes place in the contact zone, or the middle ground, and the role of the native agents had profound implications in shaping the process of the modern mission itself. Conversion is certainly a marked change in the life of the converts, but the process brings unexpected repercussions and changes to those who bring the gospel, both in the missionary persons, as well as in the organization of the mission. As Metcalf points out regarding the role of the intermediary in the Portuguese encounter with Brazil, in the 'middle ground', "minor agents, allies and even subjects at the periphery often guide the course of empires". ${ }^{16}$

Careful reading of missionary records from the days of early contact in Burma reveals the significant role the native evangelists played in the story of Karen conversion there. As the Comaroffs describe in the context of South Africa, "while (missionaries) tended to write as if their stations were founded by their own solitary exertions, the pioneer missionaries relied heavily on the help of 'native assistants', often men with extensive knowledge of the local

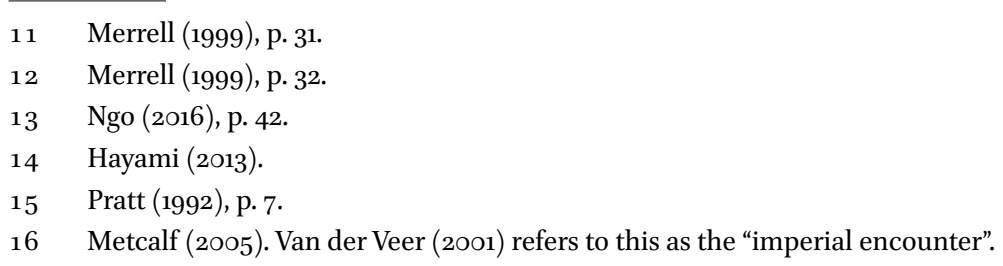


terrain". ${ }^{17}$ In most situations, it is difficult to know about the experiences of these native agents who themselves seldom left anything in written form. In the case of the Karen, we are fortunate to have not only some letters and records in the missionary periodicals, as well as Hsa Too Ghaw (The Morning Star), a vernacular monthly magazine in Sgaw Karen that was founded by the missionaries in 1842 and continued until 1942. Scattered throughout this magazine are reports from native evangelists in the field. They are neither numerous nor systematic, but they tell us some of their experiences in the field. This article makes use of some of these sources in addition to missionary reports.

To be sure, Francis Mason, one of the earliest missionaries who worked among the Karen in the nineteenth century, wrote biographies of two of the most eminent early Karen converts and evangelists, Ko Thabyu and Saw Quala. ${ }^{18}$ The biography of the former was published and read widely, not only in the United States, but also in England, Scotland, and Germany. However, these were exceptions in the master narrative of the missionary movement in Burma, which emphasized the role of the non-native missionary and rendered invisible the work of the native converts. There is a full chapter at the end of the biography that constitutes a plea to send funds for building schools, asking readers to imagine what the same amount of native zeal could accomplish once such natives could be educated. The earliest Karen converts became characters in Mason's story, in an appeal for more funding towards the mission's endeavours in education. Thus the missionaries had their own agenda in which local Karen converts had a role to play, ${ }^{19}$ but here I want to consider how, vice versa, the Karen evangelists spoke to their fellow Karen about the new teachings, in which the foreign missionaries were made to play a part.

Once we start looking into the role of the native evangelists especially in the early stages of the conversion movement, we realize that Karen conversion and their evangelistic zeal began almost simultaneously. What were the effects of this rapid evangelical movement that emerged among the Karen on the early Baptist mission? Answering this question may be another step towards understanding the establishment of the modern Protestant missions in Burma. The contact and the process of conversion itself must be viewed as a longterm, mutual process of development. On the one hand there was the evolving mission itself, with its roots in the western protestant missionary movement

\footnotetext{
17 Comaroff and Comaroff (1997), p. 78.

18 Mason (1943), and Mason (1856).

19 Fujimura (2015), pp. 295-322.
} 
and their local endeavours across the globe, and on the other, there was the world of the local converts, in this case, the Karen early converts who developed among themselves something I call a culture of evangelism. The two sides evolved in interaction, and one cannot discuss one without the other.

This article outlines this early process of development, from the initial encounter and the subsequent evangelistic process, focusing primarily on the way the mission evolved through this interaction, and on how this shaped the mission endeavour and subsequent church formation. ${ }^{20}$ This discussion begins with an examination of the first few decades of Baptist mission activities among the Karen to demonstrate the essential role that Karen converts played in the process, how the mission sought to cope with it, and how this interaction set the pattern for what follows. Then, the article looks at developments that determined the subsequent form of the mission in Burma as it expanded among other ethnic groups.

\section{The First Karen Convert and Early Evangelistic Efforts}

The first Karen conversion of Ko Thabyu (ca. 1778-1840) took place in 1828 , fifteen years after the arrival of the American Baptist missionary Judson in Burma. ${ }^{21}$ Ko Thabyu accompanied missionary George D. Boardman (1801-1831) to Tavoy (Dawei) ${ }^{22}$ to set up a mission, and was baptized there. This mission evolved rapidly thereafter. While Boardman primarily stayed in the town and the surrounding small plains inhabited by "Tavoyans", Chinese, Burman, and European populations, Ko Thabyu began to visit the hills surrounding Tavoy to preach among Karen. A simple count based on diary entries and reports, from the thirty-four months between his arrival in Tavoy in April 1828 and his death in the field in February 1831, reveals that Boardman made five trips of

20 A full exploration of the logic of Karen acceptance of Christianity and evolving of the 'culture of evangelism' among the Karen as they preached among both the Karen and nonKaren people will be for a separate discussion. Some hints on the logic can be found in the earlier work by Stern (1968), as well as in Hayami (1996). For Karen conversion in presentday Thailand, Hayami (2004), and Kwanchewan (2003), see also Horstmann (2011). For discussion of the same process from the mission perspective, see the works of Case (2005; 2012).

21 Mason (1834).

22 For place names I use the anglicized form that was used at the time, and the present-day usage in parenthesis. See also Fig. 1 for location on the map. 
mostly five days in length (so as to be back in town for every Sunday service). ${ }^{23}$ On three of these trips he was accompanied by Ko Thabyu, and visited Karen villages. Boardman also went on day trips into the villages surrounding Tavoy. Meanwhile, Ko Thabyu went out at least thirteen times, for a total of fortysix weeks. Each trip lasted between two and seven weeks. He walked in the hills for weeks at a time, among Karen in every direction, preaching to villagers who would later come to visit Boardman in Tavoy to be baptized. ${ }^{24}$ Word got around, and Karen from as far away as Mergui (Myeik, or Beik) and other parts of Tenasserim came to visit, then inviting Ko Thabyu to come to their villages. When Ko Thabyu accompanied Boardman into the hills, he would translate the missionary's Burmese into Karen, or he would speak directly to villagers in Karen. When in town, he brought prospective Karen converts to the mission station.

After the premature death of Boardman, Ko Thabyu accompanied another missionary, Cephas Bennett, to Rangoon (Yangon), where he continued this same practice of preaching tours. He spent minimal time in Rangoon, traveling extensively to preach in Karen villages in Prome (Pyay), Maubee, Pegu (Bago), and as far as the Arakan (Rakhine). Again, most of the Karen baptisms during this period were the product of Ko Thabyu's travels. In a letter addressed to Judson in Moulmein (Mawlamyaine), ${ }^{25}$ Bennett pleaded for help, requesting that some Karen assistants be sent from Moulmein to cope with the wave of converts that emerged after Ko Thabyu's travels. ${ }^{26}$ In these formative years, it was Ko Thabyu the native evangelist who set the pace for the mission's evangelistic activities.

\section{The Spoken Word}

According to Mason, a missionary contemporary of Ko Thabyu, "The baptism of Ko Thabyu in 1828 was the commencement of the (Karen) mission ... At the end of the twelve years up to his death in 1840 , one thousand two hundred and seventy Karens are officially reported as members of the churches in good standing." ${ }^{27}$ Regarding Ko Thabyu's evangelistic style, Mason writes: ${ }^{28}$

\footnotetext{
23 See, Boardman (1828) and Mason (1834).

24 Boardman (1828), pp. 166-175, 200-203.

25 Bennett (1833).

26 Mason (1856), p. 53.

27 Mason (1856), pp. 74-75.

28 Mason (1879), p. 55 .
} 


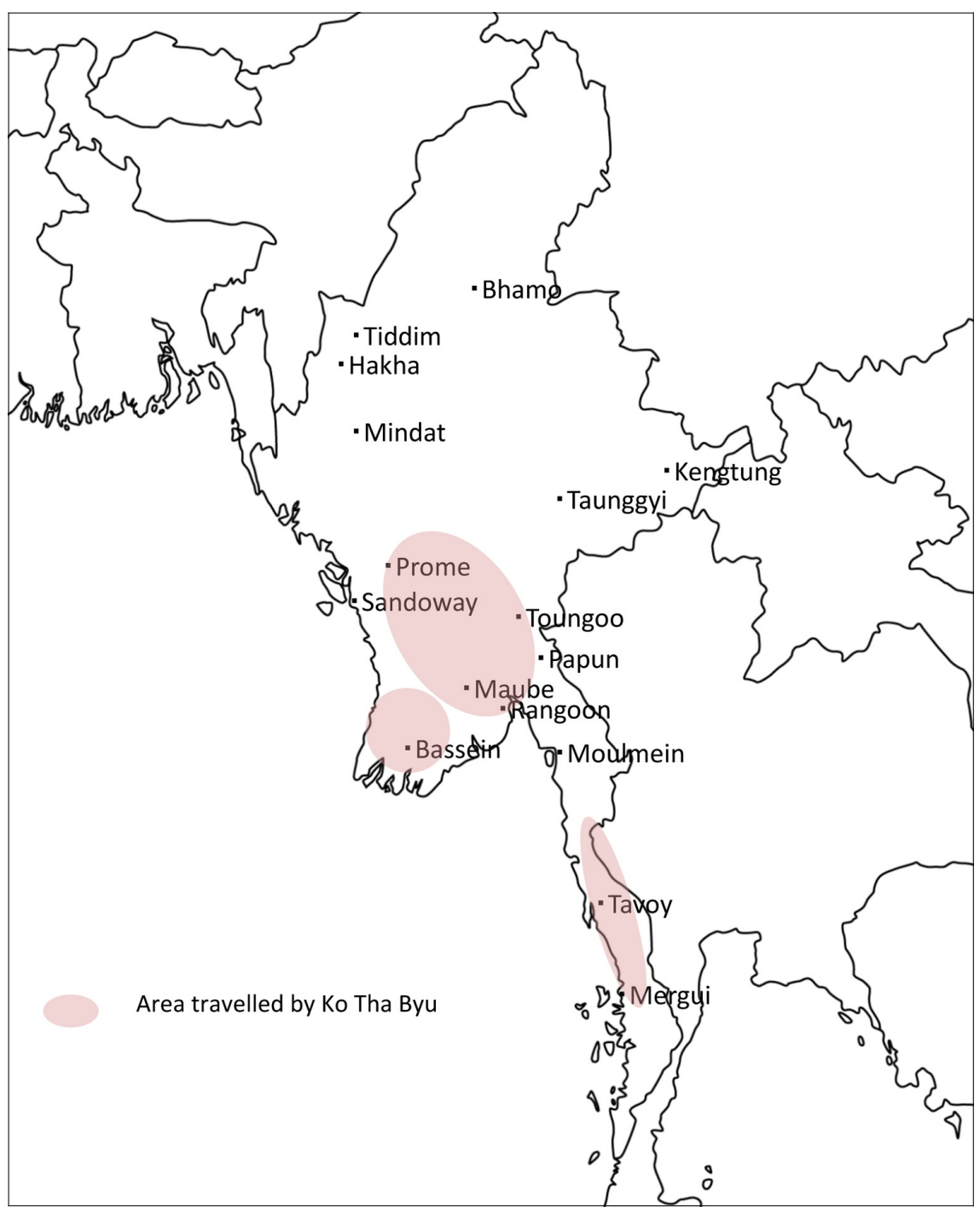

FIGURE 1 Map of the locations where the Karen evangelists travelled

Kothabyu was the most effectual preacher with the untaught Karens we ever had, and he was the most ignorant. He had very few thoughts, but these were grand ones, and everything else he deemed rubbish; the fall of man, his need of a Savior, the fullness of Christ, and the blessedness of heaven. And he used these thoughts like an auger in drilling a rock. It was round, round, round, and round, round, round, until the object was accomplished. The Christian Karens, as they became more 
fully instructed, could not bear to hear him, - they required better-educated teachers: but the schools have not turned out his equal, and probably never will, for an untaught assembly.

The importance of the written vernacular, which leads directly to the importance of literacy education, and eventually to general education, cannot be more emphasized, as we shall see in the following section. However, we must not lose sight of the importance of the spoken word throughout, but especially in the beginning, of the evangelistic encounter. If we recall the early activities of Boardman and Ko Thabyu, the first words of the gospel that reached the Karen in the hills (between 1828 and 1831) were the spoken words of Ko Thabyu. Ko Thabyu started his preaching tours in the Karen hills, where most of the hill Karen did not speak Burmese, so he was most certainly using the Karen language. Indeed, initially, none of the foreign missionaries spoke Karen, and Ko Thabyu had heard the gospel in Burmese. Being the first Karen convert, who immediately began work as an evangelist, Ko Thabyu had no Karen Bible to work with, and initially no hymns, tracts, nor any Christian discourse in the Karen language to take with him to work among his people.

Among Karen Baptists today, preaching is a highly stylized form of spoken language that makes full use of the poetic features of the language, such as alliteration and couplets. Among the first evangelists, of course, there was no such style to emulate, nor any accepted set of vocabulary with which to speak about the gospel that he himself understood. This means, whatever Ko Thabyu communicated to his people, it was his own choice of words to express the gospel. This he could do because he, as a Karen and a native speaker, knew himself what it was about the missionaries' gospel that had struck him, causing him to change his life. This is why, speaking face-to-face, amidst the lives of his Karen audience, he could preach effectively - something that none of the foreign missionaries at the time could do.

Thus, even though some of the Karen converts also spoke Burmese, the earliest wave of conversions that took place in the Tenasserim (Thaninthayi) Hills in the 183 os were primarily the result of Ko Thabyu's spoken words, though we now have no way of knowing exactly what words he used. ${ }^{29}$ Of course, it

29 In his journal, Boardman records one sample of Ko Thabyu's preaching which gained "the stillest and most profound attention" from his audience: "a worldly man is never satisfied with what he possesses. Let me have more houses, more lands, more buffaloes, more slaves, ... more gold and silver, ... let me be a rich man ... He thinks of nothing so much as of amassing worldly goods. Of God and religion he is quite unmindful. But watch that man. On a sudden his breath departs, and he finds himself deprived of all he possessed 
must be recognized that his words were backed by the presence of the white missionary, and the book of wisdom, even if nobody could yet read it, the material presence of both being crucial factors in the evangelizing process.

It is only in $183^{2}$ that missionary Jonathan Wade was persuaded by Karen converts to devise a Karen script, and the translation process noted below began in the mid-183os. Before the biblical words were carefully translated by missionaries, and subsequently printed, the initial stages of the missionary work relied heavily on the spoken word. Even after the tracts and bible were printed, and a Christian Karen vocabulary and language developed, it is still important to keep in mind that the first contact in the mission field, as we shall see below, was usually by Karen evangelists through the spoken word. It should be added, therefore, that not only the written script and printing, but also the spoken word of the vernacular delivered by their own people, speaking in terms meaningful to their own cultural context and living situation, in face-to-face contact, was a crucial factor. The written and spoken word must be recognized as two stages in the linguistic process of the missionary endeavour. As the earlier conversion was accomplished by the native speakers' use of the spoken word, in the initial encounter, the foreign missionaries were not only "less than fully in control", but continually and totally dependent on their 'assistants.' ${ }^{30}$ The native 'assistants' or evangelists, went out in full zeal, instigating the early conversion movement among Karen.

\section{Setting the Pattern}

The mission expanded rapidly during the early years. Ko Thabyu may have been an outstanding first example, but in each of the key locations of Karen conversion, there were similar Karen converts working among their own people. Already in 1836, eight years after Ko Thabyu's baptism, the mission record

and valued so much ... Astonished he exclaims, ... 'Where are my houses and my chests of money? ... And where are my wives and my children? Ah, they are all missing ... I am lonely and poor, indeed. I have nothing! ... O what a fool have I been! I neglected God, the only savior, and sought only worldly goods while on earth, and now I am undone.' ... All in this world is misery. Sickness and pain, fear and anxiety, wars and slaughter, old age and death, abound on every hand. But hearken! God speaks from on high; Children, why take ye delight, and seek happiness in that low village of mortality; that thicket of briars and thorns? Look up to me; I will deliver you, and give you rest where you shall be forever blessed and happy." (Boardman 1828 February 23). 
acknowledges: "Karen Christians are ever ready to part with their families, and go wearisome journeys of six months at a time, among distant villages where they are utterly unknown, carrying on their backs tracts and food ..."31

Furthermore, referring to the early Karen converts in Tavoy, Mason notes as follows, with a tinge of resentment in his praise: ${ }^{32}$

Preaching the gospel, with a converted Karen, is a spontaneous act. He no more thinks of asking for a license to preach, than he does for a license to pray ... Without consulting the missionary, without asking for authority or permission, without soliciting, expecting, or receiving remuneration for their labours, whenever circumstances allowed, they went out together itinerating throughout the region around. Whenever they got together an assembly, the reader read a portion of a Burman tract or Scripture, and the speaker expounded and exhorted in Karen ... This was done by "ignorant Karens," the wholly untaught sons of the forest.

The missionaries' astonishment towards this native zeal in spreading the spoken word was palpable.

After Tenasserim, and then Rangoon (Yangon), similar waves of conversion were replicated in other regions. In 1837, when the Burmese began to obstruct Christian missionizing efforts in Lower Burma, missionaries had to evacuate the area. In the meantime, Christian leadership in Lower Burma was left in the hands of two Karen evangelists (referred to as 'assistants' in mission records). When the missionaries returned to Rangoon a year later, there were more than six hundred Karen waiting to be baptized. ${ }^{33}$ Furthermore, the late 1830 s to early 184 os saw a wave of conversion in the delta area, while the missionary Elisha Abbott evacuated to Sandoway (Thandwe) in the Arakan in British territory, and had to rely on these evangelists to travel and preach. In a decision which will be discussed below, Abbott ordained two native evangelists as the first two Baptist pastors in the whole of Asia. These two ordained pastors went on to baptize over 3000 individuals in two years. ${ }^{34}$

In Toungoo, the area with the most diverse and dense population of Karen, Mason took leave due to illness, immediately after founding the mission in 1853. Another early Karen convert, Saw Quala, whom Mason refers to as "the second Karen apostle" (the first being Ko Thabyu), led the local activities in Mason's

\footnotetext{
31 Unnamed Baptist missionary in Tavoy, 1836, cited in U Zan and Sowards (1963), p. 316.

32 Mason (1856), p. 67.

33 Brockett (1891), pp. 44-45.

34 Brockett (1891), pp. 53-54.
} 
absence. By the time Mason returned two years later, twenty-eight churches had been established, and more than 2000 locals had been baptized. ${ }^{35}$ It must be noted that by this time, the Sgaw Karen bible had already been translated, and Saw Quala had been ordained following the earliest examples from the delta.

A pattern had thus been set in the early years of Karen mission. The missionaries' role was to establish the mission station and take responsibility to oversee things; to conduct Sunday services at the mission centre; to set up and maintain school education to bring up native teachers/evangelists; and to devise a script, print tracts, and translate the Bible. The Karen evangelists went into the hills, speaking the language of the people; contacting and preaching to potential converts; staying in the communities, building schools and preaching halls in the villages; and either inviting the missionary to visit, or bringing the potential converts to the missionary at the station. This was the basic division of labour that prevailed throughout the first century of mission work which later extended to work among other ethnic groups.

The process of Karen conversion in different parts of Burma can be depicted as a continual wave: in the 183 os and 1840 os this was centred in Tavoy, in the 184 os and 185os, in Rangoon and in Bassein, and in the late 185 os and 186os in Toungoo. Throughout these waves, Karen evangelists were crucial in igniting the movements. Working through face-to-face encounters using the spoken word, and traveling from village to village, they played a large role in bringing fragmented networks together into a church organization.

What, one wonders, was the source of this 'culture of evangelism', the strong desire and zeal among these initial Christian Karen that compelled them to go and teach the gospel to their own people? While this issue of the Karen side of the story needs to be developed in a separate study, I will briefly point out two factors. One is the millennialistic tendency among Karen that has been reported by various scholars. ${ }^{36}$ The other is a desire for connecting with those who share a common ethno-linguistic background. This ethno-linguistic connectivity was begun through the spoken word, and then, enormously enhanced by the devising of the written-script and its printing.

After the very first wave of conversion in Tavoy, the Karen script was devised by the missionary Wade in 1832 , as mentioned above. The first Karen tract was printed soon after, as early as in $183^{2}$. As soon as printing began in the new script, Saw Quala was sent to Moulmain to learn to read. He remained there to 
assist Mason in translating the New Testament; the method is depicted in some detail by Mason. ${ }^{37}$ Saw Quala was first asked to write down, in prose and verse, whatever Karen tradition and legends he knew, and was then sent out to collect more of such oral tradition from elders.

It has already been pointed out that translation is an essential feature of the meetings between agents of the colonizing west on the one hand and the natives on the other. As Vincente Rafael's work reminds us, ${ }^{38}$ Christian conversion is itself a process of translation, and as we have seen, the first stage was in the spoken words of the Karen evangelists, which had a significant role in the initial wave of conversion. The spoken word is vital to evangelism. Linguistic practices such as preaching, praying, and verbal confession are crucial aspects of formulating the Christian person and meaning. ${ }^{39}$

Recent scholarship on the Protestant mission has emphasized the significance of the foreign missionaries bringing script, giving written form to the spoken vernacular. The written script has done much to 'fertilize' indigenous culture, ${ }^{40}$ and the translation of the gospel also had momentous consequences, revitalizing the culture of the receiving people. ${ }^{41}$ It must also be remembered that it accompanied a homogenizing effect of a rich and varied language and culture. Once the gospel was translated into the vernacular, the native missionaries had a standard vocabulary to use in speaking to their own people. In order to translate, to produce dictionaries, grammar books, and of course the gospel, the early missionaries had to delve into the native language and culture. This was in and of itself 'a heroic deed'. At the same time, the repercussions brought by the translation were, in most instances, outside the control of the missionaries. ${ }^{42}$ It was not simply that they were now given tools to express the newly introduced ideas of the gospel, but that the use of the vernacular to express the gospel struck chords with existing ideas, stimulating and reviving, bringing new light to their native beliefs and symbols, where the converts would appropriate $^{43}$ the Christian teachings as a solution to their own cultural issues.

In the Karen translation, vocabulary, such as k'sa ywa (the Lord God), mu kho (heaven, or sky), or mu kaw li (devil or Satan) were taken from traditions collected by Saw Quala. Some words are derived from Pali Buddhist tradition

\footnotetext{
37 Mason (1856), pp. 131-133.

38 Rafael (1992).

39 Bialecki, Haynes, and Robbins (2008), pp. 1146-1147.

40 Sanneh (2009), p. 5. See also Meyer (1999), Chapter 3.

41 Etherington (2005).

42 Sanneh (2009); Rafael (1992).

43 Meyer (1999).
} 
such as ta dae ba (demerit, or sin from baap) and ta $b u$ (merit, offering from punna, merit). Mason points out that there was disagreement among Karen regarding the appropriate word for "God". In Karen tradition "Yuwah" (ywa), was a somewhat distant and not very frequently referred-to deity, "the omnipotent, omniscient and omnipresent Creator and Ruler of the world", and he adopted the word in prayer and preaching. Christians are referred to as " $b a y w a$ " (ywa-worshippers) or "ba khri" (Christ-worshippers). An alternative was "Puya" (paya), the "best term in the Burman language, which suggests a pagoda, a Buddha, or a man possessed of superhuman powers". 44

The Sgaw Karen Bible was completed and printed between 1843 and 1853 . The written script and the printing of not only the Bible (li saw sghi, the sacred book), but also books and periodicals in Karen, opened up a whole new world for the Karen. ${ }^{45}$ The earliest and longest-running vernacular monthly journal, Hsa Too Ghaw (The Morning Star) was first published in 1842. Convinced that "it is through the natives themselves that the conversion of the people will be ultimately effected," the importance of educating and training native 'assistants' was recognized from early on. ${ }^{46}$ Education in Karen began in 1835 in Moulmein, and was systematized in 1845 as the Karen Theological School. From very early in the mission, education was one of the most important means towards further evangelism. New crops of educated native evangelists emerged from among the students of the newly founded schools. After the mission's printing and teaching began, literacy was better recognized as a tool for communication and education.

\section{Uneasy Compromise: Baptism and Ordination}

The initial rush of conversion among the initial conversion among the Karen brought on questions among missionaries, who were uneasy with the rapid wave of conversion taking place, and the lack of control they had over it. The quandary was significant in the delta, where in the 1840s, missionaries had to leave Bassein which was in Burmese territory due to pressure on their activities

\footnotetext{
44 Mason (1856), pp.131-133. On the use of the term for God " $y w a$ " in Karen, see Hayami (1996). Robinne discusses, for the Kachin, how terms were similarly taken from Kachin tradition (2007), pp. 223-226.

45 An article written by a Karen evangelist in Hsa Too Ghaw Vol. 68 Issue 5, p. 75 "The gift to the Karens of a written language" expounds on the circumstances where Karen themselves pleaded for Karen scripts, and Wade responded.

46 Mason (1856), p. 165.
} 
from Burmese authorities, and evacuated to Sandoway. From there, missionary Abbott travelled every year during the dry season to visit the Karen converts along the bordering river between British and Burmese territory, to receive report from Karen evangelists inside Burma, and to baptize those who were deemed ready by these evangelists (their 'assistants'). He had to trust their testimony as to whether each convert was ready to be baptized. ${ }^{47}$

In one entry in his journal, Abbott narrates his experience one night in his boat on the river. As he rested on his vessel, mid-stream, he heard Karen voices calling him from the shore. They had come walking many days, including mothers and infants, to the meeting point on the rim of Burmese territory, choosing paths in the deep forest to avoid Burmese persecutors, to be baptized by the missionary. The missionary was taken ashore on a canoe: ${ }^{48}$

We walked two miles to a Karen village, and found the assistants engaged in a prayer-meeting. I made inquiry relative to the applicants; and as several of the assistants could vouch for them, and all agreed, I baptized fifteen in a small stream nearby. As there was a full moon and clear sky, we needed not the light of the sun. After commending them all to God, I left them, some time past midnight, and returned to my vessel.

Such entries abound during the years of the missionaries' exclusion from the rich field inside Burma. Even though the missionary trusted the 'assistants'" evaluation, and did briefly examine each candidate, the situation forced him to baptize these people with less confirmation procedures than would have been normal practice. This is a very different situation from one that Robert Frykenberg reports from among American Baptists on the other side of British territory, among the Nagas in Assam. Here the American Baptists insisted upon a "strict standard of propriety", being very careful in avoiding "premature baptisms", so much so that it "sometimes seemed as if baptism did not extend very far beyond those who served as preachers and teachers." ${ }^{49}$ Such strictness better represents the general stance of the Baptist mission towards baptism in the U.s. at the time.

Putting the matter in this general context of the times, it was indeed a daring decision by the missionaries in Bassein to ordain Karen pastors. It must have been like handing over the final key to maintaining the wedge that they

\footnotetext{
47 Carpenter (1881), Chapter 4.

48 Carpenter (1881), Chapter 3 (Abbot's diary entry from 1841 January 5 th).

49 Frykenberg (2008), pp. 437-438.
} 
had in controlling the evangelistic movement. The necessity to accommodate the wave of conversion among Karen on the Burma side at the time, meant allowing the Karen evangelists to have not only the authority to determine who was ready for baptism, but also to actually themselves baptize the converts. In this situation, the question of appropriateness of the baptisms was closely related to that of ordination of native pastors. Abbott, the missionary who stayed in Sandoway wrote: ${ }^{50}$

... if their character be like that ascribed to Bleh Po (the strongest candidate for ordination in Abbott's mind at the time, although he died before the decision was made), the danger of improper admissions (to ordination) would not seem to be greatly increased, although placed beyond the personal observation of the missionary. And the privileges of the church of Christ ought not to be unnecessarily withheld from any who are entitled to them, nor the appointed instrumentalities for its edification set aside. The case involved, on either hand, a fearful responsibility ... The ordination of native pastors over the Karen churches has been a subject of deep anxiety to me. Obliged as I am to be absent from them most of the year, and never able to visit them in Burma, the care of all the congregations is, of necessity, committed to men chosen from among themselves. No one is ever recognized by me as an 'assistant,' except upon the testimony and by the request of the people of his own village, nor until I have become satisfied that he possesses the necessary character and qualifications ... I have discouraged the idea of Karens coming ten or fifteen days' journey to be baptized by me. Why not ordain their own pastors, under whose preaching they were converted, and under whose guidance they are to live? Why not allow their pastors to baptize them at their own homes? There are hundreds of Christians in Burma who have never seen a missionary, and, unless a revolution sweep down the present monarchy, never will. They wish, of course, to be baptized; and why not ordain them pastors [parentheses by author]?

In Abbott's diary, it is noted how the Karen evangelists were themselves hesitant to be thus selected by the missionary for ordination. After agonizing over the decision, Abbott allowed the Karen congregation to choose their own pastors for him to ordain. Thus, on January 8th 1843, Abbot ordained the first two

50 Carpenter (1881), Chapter 4 (Abbott's journal, January 4th, 1843). 
Karen pastors. ${ }^{51}$ It was the only way to glean the fruits of the wave of conversion taking place in their inevitable absence.

Such decisions on the part of some of the early missionaries, to ordain native pastors, did not go uncontested. Chapin $\mathrm{H}$. Carpenter, a missionary who later succeeded the Bassein missions, notes in a commentary three decades later, "In 1843, Mr. Abbot felt compelled by his own views of duty to ordain Myat Kyau and Tway Po, notwithstanding opposition on the field, and with the doubtful approval of the executive officers after the event. The experiment succeeded so well, however, that other ordinations speedily followed in other parts of the Burman mission." ${ }^{52}$ There was still disapproval from the board at home and from some of the older missionaries in the field. "Most of the native preachers had had very little education. They were good men but hardly yet to be trusted with the care of the thirty-four churches then existing in Bassein and Arakan, but these two ordained evangelists, thoroughly trained, could do their work well, and very soon the burden was to be laid on their shoulders." ${ }^{53}$ Mason, who had in another context written approvingly of native evangelists, noted in 1843, "In my early years of missionary labour, before I was fully acquainted with native character, I was decidedly in favour of ordaining the prominent assistants: but of late I have been so fully persuaded of their general unfitness for the ministerial office, that I could not in conscience consent to the ordination of a single one with whom I have ever been acquainted." ${ }^{54}$

Carpenter seems to contradict his earlier approval of native pastors, demonstrating uneasiness towards the lack of control: 55

When the gospel was first proclaimed among the Karens of this district, it was accepted in many places by whole families and whole communities, and that, too, immediately and almost implicitly. They were ready to begin to worship the true God before they could properly be taught how to call upon his name. Educated preachers were nowhere to be found. In this extremity, each community selected from its own number the elder whom they thought best fitted to conduct their religious services. He was

$51 \quad$ Carpenter (1881), Chapter 4.

$5^{2}$ Carpenter (1881), Chapter 8; Case discusses how the debate that ensued in the American Mission was related to the formalist view on civilized ministry such as that of Mason, on the one hand, and the non-formalist view on demographic ministry such as that of Abbott, on the other (2012), pp. 48-64.

53 Brockett (1891), pp. 44-45.

54 Baptist Missionary Magazine (BMM) July 1843, p. 178.

55 Carpenter (1881), Chapter 18. 
brought to the missionary, taught a few weeks or months how to read, if he had not previously learned, then the first principles of faith in Christ, the necessity of abandoning all heathen practices, and how to perform the duties incumbent upon pastors. He was furnished with a Testament, a hymn-book and a few catechisms, and duly commissioned to the ministerial office. It was the best and only thing that could be done at the time, and these men have done an important work. If they could have been satisfied to serve the brief period they were really needed, all would have been well. One-fifth, however, of the pastors of this mission are still composed of this class, who remain incorrigibly illiterate, superstitious, and seriously obstructive. They can never be worthy of ordination, and being well supported by church-members who are their own relatives, they cannot be made to feel that it would be for the interest of the cause for them to resign, and allow some of the many educated young preachers to take their places.

There were reported cases of delinquent pastors being forced to resign by a committee of Karen elders, due to reverting to "heathen enchantments, practicing rituals in the face of family sickness, drunkenness, and adultery."56 A sense of lack of control is also expressed in the following passage: 57

It will be seen from these statements that the appointment and dismissal of native pastors is very seldom in this mission dependent upon the will of the missionary. Nowhere in the world are Baptist churches more fully or more provokingly independent in all their church polity. They are free enough in seeking the advice and aid of the missionary, and just as free in neglecting it, or setting it aside. But this is, on the whole much more cause of rejoicing than of regret: they will learn all the sooner how to govern and provide for themselves.

Thus, it was the speedy movement of the spread of conversion in its early stages that caused uneasiness and compromise on the part of the missionaries. In the early days of Karen conversion, the astonishing zeal and speed among the Karen is evident, and the missionaries had to strive to catch up with the Karen culture of evangelism.

$56 \quad$ Carpenter (1881), Chapter 18.

57 BMM July 1866: p. 253 . 


\section{Weighing the Roles of Missionary and Native Evangelist}

The debate regarding the aptitude of native evangelists as ordained pastors is also related to the constant questioning regarding the role of the native evangelists vis-à-vis the foreign missionaries, and the extent to which the missionaries could depend on the evangelists. Besides the initial wave when the speed of the movement was beyond their control, in the long run, missionaries who worked with native evangelists were realistic and aware of the division of labour. Missionaries were the pivotal figureheads, while the native evangelist did the actual daily work of evangelizing.

Half a century after the initial missionary entry among the Karen, in the Kachin field, missionary Josiah Cushing repeatedly made pleas to headquarters in America to send a foreign missionary to the Kachin. ${ }^{58} \mathrm{He}$ emphasized that the local villagers would not accept any native evangelists, unless a white missionary first went and sought permission, or unless they knew such a foreign missionary was sending these evangelists to them. While this may seem to contradict our point about the recognition of native evangelists, in the contrary, this was based on a clear recognition of a division of labour. The native evangelists were the ones who entered the hills, preached in their language, and effectively persuaded them, while the white missionaries were clearly those who gave them authority. As the mission began to take shape, this division of labour in the field seems to have been well recognized and accepted by both parties.

A later missionary notes the following on mission policy:59

The work of the missionary is largely that of our organizer and superintendent. The native evangelist, certainly among the Karens, and we judge that the same is true in most missions, is far better adapted to the work of preaching among the people, than the missionary is. He has the language perfect, he is thoroughly familiar with the customs of thought and life of the people, and can adapt himself to them, as a foreigner can never do. He is not largely an object of curiosity to the people, as the missionary is. All this in favor of the native, and against the foreign evangelist. Only by years of diligent training, close study, observation and practice can he acquire the ability of a native to reach the people. Instance the success of Quala, Dumoo, and Ko Thabyu. What missionaries have approached them?

58 Missionary Correspondences: FM13 Box 9. Folder 8. (Cushing 1877-189o).

59 Bunker (1885), p. 14. 
In response to a questionnaire from the mission headquarters in 1907, Joseph H. Cope, a missionary working among the Chin, responded as follows: ${ }^{60}$

There should be at least one missionary to every 10,00o of the people, unless indeed he could have all the native workers he could use. One missionary to 100,000 with a native worker to each 1,000 or 1,500 would be more effective than one missionary to 1,0oo with one native worker for each 5,000 or 6,ooo people. The native workers well trained by the missionary can do more work, better work and more resultful work than he can do himself let him be ever so well equipped personally. He can multiply himself in the use of these native workers as he cannot by trying to spread himself over a lot of field which he can visit but once in a period of two or three years.

\section{Self-Support and Home Missions}

An issue of fierce debate between missionaries working among Karen in the 185 os related to the system of supporting native evangelists. Missionaries in Bassein claimed the effectiveness of the self-supporting system, whereby all pastors and evangelists were in principle sustained by their own churches, which nurtured mutual obligation and interdependence between the pastor and the people. This argument was made against the system of pastors and native evangelists being paid a monthly salary from the mission. "As ten or fifteen native preachers can be supported at the cost of one foreign missionary, it has seemed wise to many friends of missions to put as many of the native Christians as possible into the direct work of evangelization. Many missions have employed a larger number of native preachers and other agents than the Christians of the country or district could possibly support."61 Thus, the Bassein and Toungoo Karen churches embraced the idea of having the local churches support, and send out their own native evangelists and native pastors. This was contrary to the system adopted by the Burmese mission, as well as the early Karen mission in Moulmein, and became a heated issue among missionaries in Burma in the mid-nineteenth century. ${ }^{62}$

\footnotetext{
6o $\quad B M M, 1907$, July 23 .

61 Carpenter (1881), Chapter 7.

62 A direct critique of the Bassein policy is found in Bunker (1885).
} 
The self-support system used for evangelical work in the Karen churches in Bassein was a design laid out by the early missionaries Abbott and Bennett. In 1850, the Bassein churches founded the first indigenous Karen Home Mission Society as a base from which to send out indigenous missionaries (both ordained pastors, as well as non-ordained evangelists) to outlying fields, with indigenous support. ${ }^{63}$ Abbott was a strong-willed and charismatic missionary who forcefully promoted the idea of self-support. There was much disagreement, though, even among missionaries working with Karen in different areas. The missions in Moulmein and Tavoy paid their native evangelists. Here, we will not go into the details of the fierce debate and the division it brought to the foreign missionaries in Burma at the time, involving the mission societies at home in the U.s., and culminating in the Bassein churches withdrawing from the larger Karen Baptist Convention at the time. ${ }^{64}$ Rather, we will here follow the path of the establishment of the Home Mission Society, and its subsequent activities, and stress that this was one outcome of the interaction between Karen evangelistic activities and the mission.

The speed of expansion and evangelistic enthusiasm was beyond the imagination of the American missionary societies. According to Mason, the Karen mission was "the cheapest of American missions in the world ... in no modern mission has an equal amount of success attended such a very small amount of funds as has been expended on the Karen mission".65

In the face of this wave of success, missionaries had to adjust, and seek ways to face the situation realistically. The ordination of native pastors, the founding of the Home Mission Society, and the self-support of evangelistic work in the Bassein churches was indeed what came out of this process. One might say that

63 After the delta became British colony following the Second Anglo-Burmese War, refugees resettled in the delta, and new associations were set up, becoming foundation for the development of self-support and sending out evangelists. This set off the momentum towards centralization by concentrating the resources at mission and education center on the one hand, and decentralization by sending out the evangelists, on the other (Maung Shwe Wa (1963), p. 113). The Rangoon Home Mission Society was founded in 1853. Later they decided to finance their own evangelical activities (Maung Shwe Wa (1963), pp. 172175).

64 When the Bassein decision was reported to the American Board, there was much skirmish, as the board was unimpressed, and stopped all aid to the association. In protest against this action, the Bassein missionaries and association absconded from the board (Maung Shwe Wa (1963), p. 175) and joined the Free Mission Society.

65 Mason (1856), pp. 74-75. 
the missionaries in Bassein re-appropriated the Karen culture of evangelism towards designing the system of self-support which is therefore, a product of this mutual interaction.

The following are the words of the missionary Abbott, upon the founding of the Home Mission Society in Bassein, 1850:66

That missionaries are going into every small village, or city even, of Burma or China, is not to be thought of for a moment ... Heathen countries must be evangelized through a native ministry. That ministry must be educated by foreign aid. Give to them and their country the Bible and theology, education to teachers and ministers, books etc., and a general guidance such as Paul gave to the churches he had planted ... But these ministers, when educated must not become the hired men of the missionary. After we have given to the country or people an educated ministry, teachers, the Bible, and a literature, the rest must be self-sustaining. Karens must sustain Karens, is a sentiment I have re-iterated to our native preachers here.

In the midst of disagreements among missionaries, the Karen churches, mostly in Bassein, responded well to the new system, and began to send out their own evangelists, who they themselves supported. Upon the founding of the Home Mission Society, churches that had been making annual contributions to the mission devoted their funds specifically to the purpose of sending evangelists, and in 1853 , eleven Karen evangelists were sent out. ${ }^{67}$ Initially, the mission fields were in the surrounding Karen populations of both Sgaw and Pwo. Karen evangelists were sent by this Home Mission Society to be among the Karen, including those in Siam. Eventually, though, they were sent farther to Prome in 1853, to Toungoo in 1854, and then, further afield as we shall see below. By 1854, the Bassein churches became self-supporting in terms of evangelical work, voting to no longer receive funds from the American mission for the purpose of evangelism.

Thus, the early days of the Karen mission laid the foundation for the formation of modern missions in Burma, which emerged from the dialectic between the Karen evangelistic zeal and mission response, appropriation and re-appropriation, and the negotiation and compromise that came as a result of this interaction. The policy of self-support was later widely adopted, and Home

66 Carpenter (1856), Chapter 8.

67 Carpenter (1856), Chapter 11. 
Mission Societies founded in various parts of the mission. Self-support would ultimately become a desired goal and marker for an independent church. Thus, in 1924, when the British government took over all the mission schools and directly hired the Karen teachers among the Chin Hills, who had until then been hired by the Chin mission, then missionary Cope noted, "the tithes and offerings of the Chin Christians reached the point of paying for their Chin pastors and thus we can say that the churches have achieved self-support." 68

A similar process is described by the Comaroffs as happening in Africa around the same period. They write of the historical process by which missionaries among the Tswana went through processes of trial and error in their mission work, and the debates and disagreements among them. ${ }^{69}$ The eminent missionary David Livingstone had ideas that were very similar to those of Abbot, holding that "minimally supervised native agency was the only practical means of provisioning Africa with the bread of life ..." ${ }^{70}$ Livingstone professed to a strong sense that, "if not kept on perpetual leading strings by European authority, blacks sic. would make the most efficient evangelists, cultivating a robust, locally tuned Christianity."71

\section{Native Mission Work among Non-Karen 'Others'}

Mission among non-Karen also evolved in the initial stages through the interaction between the Karen evangelists and missionaries, and are also pertinent to our discussion. In 1856, the Bassein Home Mission Society sent six Karen evangelists to Toungoo, two to Henthada, and two to Prome. ${ }^{72}$ Those in Prome came across the "Asho" Chin community in the area, and ten Chin soon converted. The children entered Karen schools in the delta. A Pwo Karen ordained evangelist, Myat Goung, employed by the Burma Baptist Convention to work among the Chin, devised the first Asho script based on the Pwo Karen script in 1865 , and published a hymnbook and spelling book (though the script was

68 Cited in Sakhong (2003), p. 169. Frykenberg (2008, p. 442) points out that in Naga fields in Assam in early twentieth century, the peripheries of the Raj, the Ao Naga villages were selfsupporting village congregations. From Africa, those missionaries who travelled among the villages, such as Livingstone, were of the idea that the indigenous churches should be self-supporting (Comaroff and Comaroff, (1997), p. 83).

69 Comaroff and Comaroff (1997), pp. 65-75.

70 Cited in Comaroff and Comaroff (1997), p. 83.

71 Cited inComaroff and Comaroff (1997), p. 83.

72 Carpenter (1881), Chapter 13. 
later revised by a missionary). In 1861, thirty-five Karen evangelists were commissioned, some for a few months and others for six months to a year, and sent to Toungoo and Prome, as well as to northern Siam, and areas where Chin, Karenni, "Bghai", "Toungthoo", "Paku", and "Gecko" reside. ${ }^{73}$ In 1862, missionary Eugenio Kincaid reported the following from Prome: ${ }^{74}$

I have frequently mentioned the young Karen preachers from Bassein. They were supported for a year by the Bassein churches. I have now assumed their support. Up to this time, twenty have been baptized as the result of their labours. And this is not the only result ... Twenty or thirty have been taught to read the word of God in their own language ... These preachers are both first class young men, and have been remarkably well instructed in the Scriptures ... I am under great obligations for such faithful and well-trained fellow-labourers, - men who are not eyeservants, and do not need prompting to go into the field, and work -.

In 1877, missionary Cushing, accompanied by two Karen evangelists from Bassein, set up a mission station in Bhamo to work among the Kachin. At first, it was presumed that the Kachin were a subgroup of Karen and that the language would therefore be similar and easy for the Karen to learn. The Karen evangelists learned the language, which they found to actually be very different from Karen, and worked under the guidance of missionaries. The initial transcription of the Kachin language, Jingphaw, was a joint effort between Cushing and Karen evangelists, mixing Burmese, Shan, and Karen scripts (in 189o, a Romanized script was devised by Ola Hanson, another missionary).

While missionaries came and went, especially during the war in Upper Burma in the 188os, Karen evangelists stayed on. The first Kachin baptism was the fruit of Karen labours in the absence of any missionary in Bhamo. The Karen evangelist Koteh wrote in a letter to a missionary that he and his co-worker S'Peh had successfully persuaded nine prospective converts in Bumwa Village, where S'Peh had been working. ${ }^{75}$

... Dear Teacher and Mama. I have been in this place of labour about four years. I have worked, and watched the hearts of this people, and it seems as if the kingdom of Christ will verily send out its roots here.

\footnotetext{
73 Brockett (1891), p. 82.

74 Carpenter (1881), Chapter 15 .

75 вмм 1882 March, pp. 71-72.
} 
For last August, I went to brother S'peh's for more than a month, and we preached to his villagers, and showed the way just as exactly as we could. Two houses ... have agreed that they will worship the Eternal God. We have watched them to see if their life corresponds with their promise ... As to the nats, ... our two families no longer join in ... They no longer drink arrack. They fully purpose to worship God, and we will watch over them till after harvest. If at that time their course has been satisfactory, we will call the Teacher from Bhamo and Teacher Mau Keh (the ordained Karen missionary) to come and cause them to become Christ's disciples. If these two houses become the first-fruits, we hear that many persons and many villages say that they will follow them.

In March 1882, upon return from furlough, missionaries visited Bumwa Village to confirm their faith, and baptized seven converts in the presence of four Karen evangelists. ${ }^{76}$ The baptismal formula was translated into Jingphaw by the Karen evangelists. ${ }^{77}$ In the first Kachin communion that followed, the Karen evangelist read a passage from the Karen Bible and explained the meaning of the rite in Jingphaw.

The Kachin mission expanded after Upper Burma was incorporated under British administration. Over the wide expanse of Kachin land, the same pattern was replicated wherever Karen evangelists, mostly from Bassein, resided. The first baptisms in Myitkyina took place in 1897. Different subgroups of the Kachin, the "Lashi" and "Rawang", were similarly initially reached by Karen evangelists by the 1920s. The Karen evangelist Ba Thaw also reached the Lisu in 1911, and developed a written form of their language, and then went as far as China. In Shan State, too, a Karen was sent to Namkham to work among the Kachin there.

When missionaries began to work in the Chin Hills in 1899, Karen evangelists from Henzada (Hinthada), Bassein, Sandoway, and Prome joined to assist them, until Chin leaders were trained enough to carry on the work. ${ }^{78}$ Karen evangelists and teachers worked across the vast Chin Hills from Hakha in the south to Tiddim, and to Falam in the north. Here, the division of labour between the missionaries and the Karen evangelists was not only in the type of work, but was also geographical and, to a certain extent, linguistic. Foreign missionaries were stationed first in Hakha, and later also in Tiddim. The northern hills

\footnotetext{
$76 \quad$ BмM August 1882, pp. 306-307.

77 Tegenfeldt (1974), p. 105.

78 U Zan and Sowards (1963), p. 346. Cin Do Kham (1999), p. 211.
} 
were difficult to access, and were linguistically diverse. In the initial stages, while missionaries worked in Hakha using the local Hakha language, the Karen evangelists were dispersed in the hills northwards to learn the various local languages.

Thra Shwe Zan, a Karen evangelist from Bassein, was stationed in Hakha from 1901, and later moved to a village in the northern Siyin Chin Hills in Khoset (Khuasak) in 1904. He led the first hill Chin conversion of two village headmen and their wives. In 1906, the first Chin Baptist church was founded in the Siyin Valley under his leadership. The testimony of missionary Cope demonstrates the depth and extent of Karen evangelists' involvement in the founding of the ethnic Chin church: ${ }^{79}$

We owe everything to the Karens. We do not know what we would do without them. When Mr. Carson first came up he brought three or four Karens with him and from that time on, with a few exceptions, they have proven splendid men on whom one could place no end of responsibility. For a long time they were the only evangelists here. They went out to strange villages where no preparations had been made for them, and where they were threatened direly. The first Chin Christians came seven days' journey from Hakha where a Henzada Karen, Thra Shwe Zan, worked alone, seeing the missionaries only once a year. The Chin preachers were put under these Karens and some of our finest workers were trained by them. They learned the language, learned the ways of the people, and won their confidence. In the first literary work I did, it was the Karens who helped me. In the school work as well we have Karen Headmasters, and they proved as valuable there as in the evangelistic work.

Later, in 1917, Cope notes in a letter addressed to Boston that there is a large number of conversions in spite of the absence of a foreign missionary: "Most of these have come from villages distant from Hakha where all the work was done by the Karen and Chin workers. These men have steadily gone on with their work and accomplished results." 80

As in the other missions, in the early days, the Karen evangelists spoke the vernacular without the benefit of any written text. The missionaries were not able to do any formal translation of the Bible during the early years in

79 Cited in Johnson (1999), p. 28.

8o Missionary Correspondence microfilms: FM 184 Box1o6. Folder 5 (Cope Jan. 2, 1917). 
Hakha, during which time Karen preachers worked out what missionary Henry Tilbe called 'colloquial translation of the scripture lessons' to accompany their sermons "so in fact the Chins first began to hear the Bible read by these down country evangelists". 81

While entries in Hsa Too Ghaw (Morning Star, the Sgaw Karen magazine) by Karen evangelists in the Chin field are scarce, a few mentions of their use of language are indicative of their general stance towards native languages. Thra Shwe Zan writes: ${ }^{82}$

While I was still at Haka I was familiar with that language. However, when I arrived Khoset village, Haka language helps me no more. So I have to struggle for the new language in order to preach. I preach as much as I know to the Chins here and help their children to be able to speak Burmese and the language of God, i.e. to develop them both spiritually and physically.

This is the beginning of a long report which describes, ethnographically, the "Siyin" Chin people, and then the converts in the village, including the two very first Chin couples who were baptized a year before. Four years later, another Karen missionary reports on a trip in which he, two other Karen, Shwe Zan and Pho Ku, two long-time workers in the northern hills, two Chin missionaries from the south, and the missionary doctor Dr. Erik H. East take a trip. He testifies, "we reached another country and if it was not for Thra Pho $\mathrm{Ku}$ and Thra Shwe Zan no one could speak the language." 83 In his missionary correspondence, East himself states that, in Tiddim, he thought it sufficient to use Burmese. It was thus the Karen evangelists who were most conscious and effective in using the local vernacular, and so in preaching the gospel directly to the locals.

Karen evangelists also worked in Shan State, in Taunggyi and Kengtung, especially among the Lahu, Wa, and Pao. In 1927, James Telford, a missionary in Kengtung, wrote: ${ }^{4}$

A historical sketch of the Kengtung Mission would not be complete if we failed to make mention of the great part the Karen Christian workers

\footnotetext{
81 Johnson (1988), p. 70.

$82 \quad H s a$ Too Ghaw, Vol. 64, Issue 10, October 1905.

83 Hsa Too Ghaw, Vol. 68, Issue 6 p. 88. "Preaching tour among the Chins" by Maung Ku. June, 1909.

84 Cited in U Zan and Sowards (1963), p. 318.
} 
have had in the development of the Lahu church ... much of the success ... has been largely due to their splendid consecration and complete abandonment to the work. For years the Karen churches of Bassein ... have sent evangelists and pastors to the Lahus for whose financial support the Karen churches have assumed entire responsibility, the services over a period of years by such men as Po Tun, Ba Te, Chit Swe, and numerous others, live as a fragrant memory in the hearts of the Lahus.

Thus, we find that in the formation of the Chin, Kachin and Lahu Baptist churches, which today, along with the Karen, constitute the major ethnic church organizations in Myanmar, Karen evangelists were prominently involved from the early stages. The first converts were consistently the product of the work of Karen evangelists who stayed in one locale and persisted for several years before conversion took place. As Ko Thabyu had done among the Karen, the early evangelists entered the hills without having any translated text to take with them. It was their words that first reached the people in their own language. Living among the native peoples, the Karen evangelists had good knowledge of the context of the everyday life surrounding them, so that they not only knew their languages, but also how to speak to them effectively with that language: teaching them to sing hymns, and talking to them daily. They assisted the missionaries, just as they had done among their own people, and played a significant role in setting up the crucial foundations of these ethnic churches. By then, the Karen evangelists, as well as the missionaries, knew their part well: the Karens would go and live among the people and persuade them to engage in this new way of life. Then, the Bible and education would be prepared by the missionaries and brought to them.

Through these endeavours, an initial pattern of church formation among the Karen was replicated among other ethnic groups by the joint work of foreign missionaries and the mainly Karen evangelists. The initial evangelistic zeal, the 'culture of evangelism' has thus evolved, to spread the word among not only their own groups but across other language speakers, by the evangelists trained and educated in the seminaries set up by the mission. Karen evangelists who preached in the local vernacular were a vital presence in the Burma mission, and their contribution shaped the mission endeavour from its very beginning, first in the work among their own people, and then among other groups. 


\section{Conclusion}

This article has followed the early progress of the modern Protestant missions in Burma, with a focus on Karen indigenous evangelists, and how their activities gave shape to the development of the mission. From the very beginning, there was an urge among some Karen converts to go out and spread the gospel, developing a culture of evangelism. This strong impetus to preach and spread the word superseded the foreign missionaries' plans and expectations. In many instances, the foreign mission was forced to reconsider their own ideas on issues such as baptism, ordination, or the roles of the missionary and the native evangelist. The interaction that took place, and the dynamics between the native evangelists and the missionaries did much to shape the mission, and the ethnic-based organization of the Baptist churches. Criteria regarding how to determine readiness for baptism, what counted as confirmation of faith, consideration for ordaining native pastors, and how to remunerate indigenous workers, were all shaped and formulated along the way in a process of trial and negotiation, a process in which native Christians played an essential role. The division of roles was such that Karen evangelists worked with the potential converts, both among their own people, as well as among non-Karen others. They devised the first words with which to speak to and persuade those they encountered. If conversion took place, it was because the evangelists had successfully spoken things that resonated in the recipient's lives and minds. Thus, the Karen evangelists were not only essential to the actual missionary endeavour, and the formation of Karen and other ethnic churches, but they were also important players in the process of the formation of the modern Protestant mission.

This is but one story from the early period of modern Protestant missions. The modern mission, as was initiated in the late eighteenth-century in the Western world, was in its incipient stage in innumerable contact zones the world over. Everything took shape as it evolved, and in negotiation with the indigenous evangelists who had their own people behind them, and their missionary overseers, who in turn had to respond to the missionary boards in their home country.

Not only did the native evangelists hold 'the trump card'85 in their command of the vernacular, it almost seems in many respects, as if they were in control

85 Sanneh (2009), p. 196. In a similar vein the Comaroffs refer to the native agency as being like the black figures in the kabuki theater, which are actually moving the puppet characters on stage (they might perhaps be referring to the bunraku puppets. Comaroff and Comaroff (1991), p. 78). 
of the stage and the drama in which the foreign missionaries were unwittingly playing the supporting role by authenticating the spoken word of the native evangelist. Thus, the next question is, what chords did the spoken words of the native evangelists strike, what instigated the mass conversion, and how did it translate into other non-Karen converts? In other words, what actually spurred the culture of evangelism into motion, and what happened when its momentum crossed ethnic borders? These questions may lead us, by dissecting the Karen culture of evangelism as it evolved, to further question the overemphasis on the modernist understanding of the Protestant mission.

\section{References}

Bialecki, Jon, N. Haynes, and J. Robbins. (2008). The Anthropology of Christianity. Religion Compass 2/6, pp. 1139-1158.

Boardman, George D. (1828). Memoirs of George Boardman. Baptist Missionary Magazine.

Brockett, L.P. (1891). The Story of the Karen Mission in Bassein 1838-189o. Philadelphia: American Baptist Publication Society.

Brown, Judith M., and R.E. Frykenberg, eds. (2002). Christians, Cultural Interactions and India's Religious Traditions. Cambridge: Win B. Eedermas publishing Co.

Bunker, Alonzo. (1885). A Review of Reverend C.H. Carpenter's 'Self-support' and Our Mission Policy: A Study in Mission Methods. Toungoo: Karen Mission Press.

Carpenter, C.H. (1881). Self-Support: History of the Bassein Karen Mission: 1840-1880, Boston: Franklin Press.

Case, Jay Riley. (2005). Interpreting Karen Christianity: American Baptist Reaction to Asian Christianity in the Nineteenth Century. In: L. Sanneh and J. Carpenter, eds., The Changing Face of Christianity: Africa, the West, and the World. Oxford University Press, pp. $135^{-15^{8}}$.

Case, Jay Riley. (2012). An Unpredictable Gospel: American Evangelicals and World Christianity 1812-1920, New York: Oxford University Press.

Cin Do Kham. (1999). The Untold Story: the Impact of Revival among the Chin People in Myanmar (Burma). Journal of Asian Mission 1/2, pp. 205-222.

Comaroff, Jean. (1985). Body of Power Spirit of Resistance: The Culture and History of a South African People, Chicago and London: The University of Chicago Press.

Comaroff, Jean and John. (1991). Of Revelation and Revolution: Volume 1, Christianity, Colonialism, and Consciousness in South Africa, Chicago: The University of Chicago Press.

Comaroff, Jean and John. (1997). Of Revelation and Revolution Volume 2, The Dialectics of Modernity on a South African Frontier, Chicago: The University of Chicago Press. 
Etherington, Norman. (2005). Introduction. In: N. Etherington, ed., Missions and Empire, Oxford: Oxford University Press, pp. 1-18.

Frykenberg, Robert Eric. (2005). Christian Mission and the Raj. In: N. Etherington, ed., Missions and Empire, Oxford: Oxford University Press, pp. 107-131.

Frykenberg, Robert Eric. (2008). Christianity in India: From Beginnings to the Present, Oxford: Oxford University Press.

Fujimura, Hitomi. (2015). Reconsideration of the Karen Image in Mid-Nineteenth Century Burma within the Context of the American Baptist Mission(in Japanese). Tonan Ajia Kenkyu, 52(2), pp. 295-322.

Hayami, Yoko. (1996). Karen Tradition According to Christ or Buddha: the Implications of Multiple Reinterpretations for a Minority Ethnic Group in Thailand. Journal of Southeast Asian Studies 27(2), pp. 334-349.

Hayami, Yoko. (2004). Between Hills and Plains, Power and Practice in Socio-Religious Dynamics among Karen. Kyoto: Kyoto University Press and Trans-Pacific Press.

Hayami, Yoko. (2013). Transnational Mission among Karen: Cross-border Connections, Ethnicity and Christianity. In: Proceedings of Kyoto-Cornell Joint International Workshop on Trans-national Southeast Asia: Paradigms, Histories, Vectors, Kyoto, pp. 399-424.

Horstmann, Alexander. (2011). Sacred Networks and Struggles among the Karen Baptists across the Thailand-Burma Border. Moussons 17, pp. 85-104.

Johnson, Rev. Robert G. (1999). The first Chin Baptist churches. In: Rev. Cung Lian Hup, ed., Thinking about Christianity and the Chins in Myanmar, Yangon: published by the editor, pp.1-4.

Johnson, Robert C. (1988). History of the American Baptist Chin Mission 1899 to 1966. Limited edition. Atlanta: American Baptist Historical Society.

Kwanchewan Buadaeng. (2003). Buddhism, Christianity and the Ancestors: Religion and Pragmatism in a Skaw Karen Community of North Thailand. Chiangmai: Sprint.

Mason, Francis. (1834). Traditions of the Karens. Baptist Missionary Magazine XIV: pp. 382-393.

Mason, Francis. (1843). The Karen Apostle: or Memoir of Ko Thabyu. Boston: Gould, Kendall and Lincoln.

Mason, Francis. (1856). Sau Quala; the Second Karen Convert. Baptist Missionary Magazine $36: 1$.

Mason, Francis. The Story of a Working Man's Life. NY: Oakley, Mason and Co.

Maung Shwe Wa. (1963). Burma Baptist Chronicle Part I. Rangoon: Board of Publications, Burma Baptist Convention.

Merrell, James H. (1999). Into the American Woods: Negotiators on the Pennsylvania Frontier. New York: Norton and Company.

Metcalf, Alida C. (2005). Go-betweens and the Colonization of Brazil, 1500-1600. Austin: University of Texas Press. 
Meyer, Birgit. (1999). Translating the Devil: Religion and Modernity among the Ewe in Ghana. Trenton, NJ: Africa World Press.

Ngo, Tam T.T. (2016). The New Way: Protestantism and the Hmong in Vietnam. Seattle: University of Washington Press.

Pratt, Marie Louise.(1992). Imperial Eyes: Travel Writing and Transculturation. New York and London: Routledge.

Rafael, Vincente L. (1992). Contracting Colonialism: Translation and Christian Conversion in Tagalog Society under Early Spanish Rule. Durham: Duke University Press.

Robinne, François. (2007). Prêtres et chamanes. Métamorphoses des Kachin de Birmanie. Paris: L'Harmattan.

Sakhong, Lian H. (2003). In Search of Chin Identity: A Study in Religion, Politics and Ethnic Identity in Burma. Copenhagen: NIAs Press.

Sanneh, Lamin. (2009 [1989]). Translating the Message: The Missionary Impact on Culture, 2nd edition. New York: Orbis Books.

Sharkey, Heather J., ed. (2013). Cultural Conversions: Unexpected Consequences of Christian Missionary Encounters in the Middle East, Africa and South Asia. Syracuse: Syracuse University Press.

Sowards, Genevieve and Erville Sowards, eds. (1963). Burma Baptist Chronicle. Pt. II. Rangoon: Board of Publications, Burma Baptist Convention.

Stern, Theodore. (1968).Ariya and the Golden Book: A Millenarian Buddhist Sect among the Karen. Journal of Asian Studies 27(2), pp. 297-328.

Tegenfeldt, Herman G. (1974). A Century of Growth: the Kachin Baptist Church of Burma. Pasadena: William Carey Library.

U Zan and Erville Sowards. (1963). Baptist Work among Karens. In: G. Sowards and E. Sowards, eds., Burma Baptist Chronicle. Pt. II. Rangoon: Board of Publications, Burma Baptist Convention, pp. 304-326.

Van der Veer, Peter. (2001). Imperial Encounters: Religion, nation, and Empire. Princeton: Princeton University Press.

Missionary Correspondences (microfilms at the American Baptist Missionary Archives)

FM13 Box9. Folder 8. (Cushing 1877-189o)

FM 184 Box106. Folder 5 (Cope)

\section{Periodicals}

Baptist Missionary Magazine (BMM)

1833 October

1843 July

1866 July

1882 March 


\section{August}

1907 July

Hsaa Too Ghaw (The Morning Star)

Vol. 64 Issue 10 (October 1905)

Vol. 68 Issue 5 (May 19o9)

Vol. 68 Issue 6 (June 19o9) 